\title{
罹病残さの嫌気的発酵によるダイコン萎黄病菌 の不活化に対する発酵時の温度の影響*
}

\author{
萩原 廣**・竹内昭士郎**

\begin{abstract}
Hiroshi HAgIWARA** and Shoshiro TAKEUChI**: Effect of Temperature on the Inactivation of Fusarium oxysporum f. sp. raphani through
\end{abstract} \\ Anaerobic Fermentation of Radish Residues*
}

\begin{abstract}
The effect of temperature on the inactivation of radish yellows pathogen (Fusarium oxysporum f. sp. raphani) during anaerobic fermentation of radish residues was examined. The debrises of diseased radish roots were anaerobically fermented under the different temperatures, by sealing up in plastic-film bags. Either at varying or constant temperature in the range from 10 to $30 \mathrm{C}$, the higher the temperature, the faster the inactivation of the pathogen progressed. Inactivation of the pathogen occurred obviously with the progress of fermentation.
\end{abstract}

Key Words : eradication, Fusarium oxysporum, crop residue, anaerobic fermentation.

先に，筆者ら ${ }^{1)}$ は, ダイコン萎黄病罹病残さを堆積 し，塩化ビニルフィルムで被ふく密封することによ り，本病病原菌が不活化することを見出し，この現象 が，ダイコン残さの嫌気的発酵によって生じた可能性 があると推定した。本報では，ダイコン残さの嫌気的 発酵に伴ら本病菌の不活化を確認すると共に, 発酵温 度が不活化に及ぼす影響について報告する。

本病に罹病して道管部の変色を生じた株を含むダイ コン（品種：長交耐病総太）の根部を, 長さ約 $5 \mathrm{~cm} の$ 輪切りにし，厚さ $0.05 \mathrm{~mm}$ のポリエチレン膜二重袋 の中に $4 \mathrm{~kg}$ ずつ詰め, それぞれの袋の口をゴムバン ドで封じて密封した。これらを, 所定の温度条件下で 一定期間発酵させた後, 残さ中の本病菌の活性の有無 抢よび残さの性状の変化を検討した。病原菌の活性 は, 前報1) と同様の方法で, 変色道管部を含む切片か らの Fusarium oxysporum 検出之, 同切片を混入し た土壌には種したダイコン幼苗の発病とによって検討 した。処理後の試料の色や固さほ肉眼的観察により, 水素イオン濃度 $(\mathrm{pH})$ は, 細切した根部試料 $20 \mathrm{~g}$ を $50 \mathrm{ml}$ の蒸留水中に入れ, 室温下30分間静置して得た
浸出液について, 日立堀場社製 M-7 II 型 $\mathrm{pH}$ メータ によって測定した。処理温度は, 変温条件（試験 I ) と恒温条件（試験I）とに分けて行った。試験 I で は，20〜30 C の温室内に置いた場合（高温）と，5～ $15 \mathrm{C}$ の室内に置いた場合（低温）を設け，それぞれ

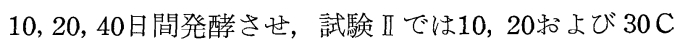
の恒温器内で，それぞれ $1 ， 2 ， 4 ， 8 ， 16 ， 32$ 日間発 酵させた。対照としては，残さを入れたポリエチレン 袋の口を密封せず, $10 \mathrm{C}$ の恒温器内に置いたものを用 いた。罹病残さは, 約 $5 \mathrm{~cm}$ の輪切りにした根部を各 処理につき 3 個ずつ供試し，いずれも 2 反復した。

試験 I では，F. oxysporum 検出和よび幼苗の発病 ともに，低温下10日間発酵区でのみ認められ，それ以 外には全く認められなかった（Table 1)。

試験 II の結果を Fig. 1. 亿示す。対照区では, $F$. oxysporum 検出組織片率（菌検出率）特よび発病株 率ともに $100 \%$ に近い值が32日目まで維持されたが, 密封して発酵処理を行った場合には，いずれの温度下 に揖いても，時間の経過と共に低下した。また，両者 の低下は，発酵時の温度が高いほど速かであった。す

* 本稿の概要は，昭和 57 年 10 月 15 日の日本植物病理学会関西部会で報告した。

** 野菜試験場 Vegetable and Ornamental Crops Research Station, Ano, Mie, 514-23, Japan

1) 萩原 廣・竹内昭士郎 (1982). 日植病報 48:688-690. 
Table 1. Activity of radish yellows pathogen in radish roots after anaerobic fermentation under different temperature

\begin{tabular}{cccc}
\hline \hline Temperature (C) & $\begin{array}{l}\text { Fermentation } \\
\text { period (days) }\end{array}$ & $\begin{array}{l}\text { F. oxysporum } \\
\text { detection }(\%)^{\mathrm{b})}\end{array}$ & $\begin{array}{l}\text { Diseased } \\
\text { plants }(\%)^{\mathrm{c})}\end{array}$ \\
\hline Low (5-15) & 10 & 29.2 & 34.8 \\
& 20 & 0 & 0 \\
High (20-30) & 40 & 0 & 0 \\
& 10 & 0 & 0 \\
Not fermented & 20 & 0 & 0 \\
& 40 & 0 & 0 \\
\hline
\end{tabular}

a) Range of varying temperature (minimum-maximum)

b) About 50 pieces of radish residues containing discolored vascular bundle were incubated with Komada's medium for 35 days under $20 \mathrm{C}$.

c) Vascular browning was examined about 60 hypocotyles of radish plants grown on the soils mixed with fermented residues for 30 days under 15-30 C.

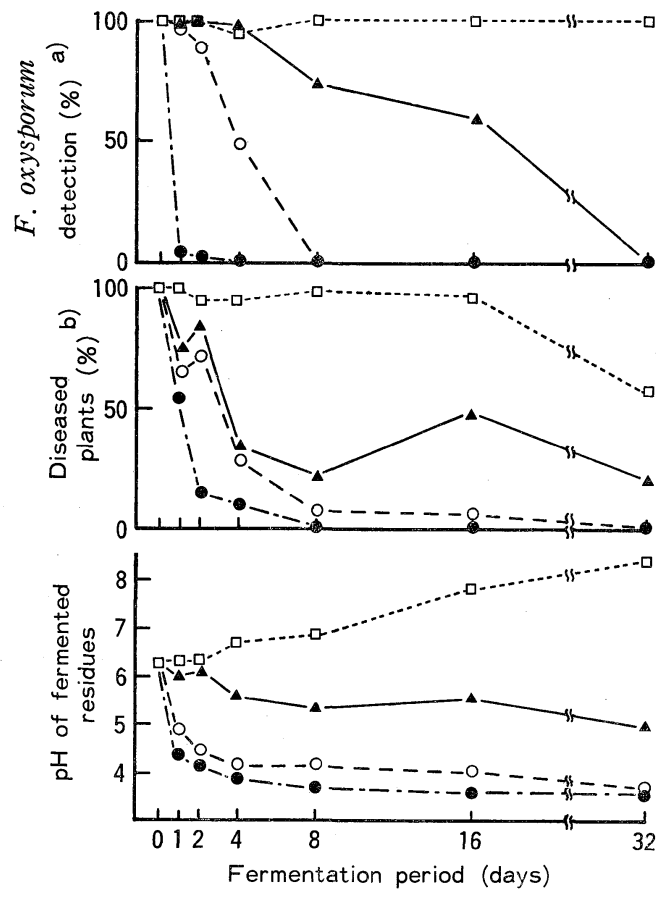

なわち, 菌検出率は, $30 \mathrm{C}$ 下では 4 日目以後, $20 \mathrm{C}$ 下 では 8 日目以後，10C下では 32 日目には 0 となり，発 病株率も30C下では 2 日目以後, $20 \mathrm{C}$ 下では 8 日目以 後著しく低い值となった。な拉，両者の低下はほぼ平 行的であったが, 概して, 発病株率に比し, 菌検出率 の低下がより速かであった。一方，ダイコン根部組織 は, 発酵の進行に伴い, 水分が浸出して柔軟さを増し
Fig. 1. Effect of temperature for anaerobic fermentation of radish roots, previously infested with radish yellows pathogen, on the activity of $F$. oxysporum, and $\mathrm{pH}$ of the residues.

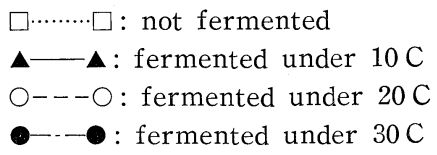

a): About 70 pieces of radish residues containing discolored vascular bundle were incubated with Komada's medium for 35 days under $20 \mathrm{C}$.

b) : Vascular browning was examined about 60 hypocotyles of radish plants grown on the soils mixed with fermented residues for 30 days under $15-30 \mathrm{C}$.

たが，崩壊することはほとんどなかった。その色は， 白色からしだいに黄色, 黄褐色, ついには淡褐色に変 色乙, 試料の $\mathrm{pH}$ は, 処理前の $\mathrm{pH} 6$ 付近か $5 \mathrm{pH} 4$ 前 後に低下した。これらの形状の变化も, 発酵時の温度 が高いほど速かで，菌検出率括よび発病株率の低下と ほぼ平行していた。これに対して，対照区の根部組織 は8日目ごろから黄褐色に変色して腐敗し始め, その 
後組織が崩壊して $\mathrm{pH}$ も8 付近まで上昇した。 新鮮な植物組織をポリエチレンフィルムなどを用い て密封すると，内部の酸素は短時間内に消費され，植 物組織の嫌気的な発酵が起こり，有機酸の生成ととも に $\mathrm{pH}$ が低下することが知られている2)。本試験で観 察されたダイコン残さの形状の変化や $\mathrm{pH}$ の低下は, それらが嫌気的に発酵したことを示している。また， 処理後の罹病残さからの $F$. oxysporum 検出打よび 残さ混入土壌には種したダイコン幼苗の発病は，とる に, 残さの発酵の進行に伴って低下して拉り，本病菌 の活性がダイコン残さの嫌気的発酵の過程で失なわれ ていることは明らかである。

本試験で， 発酵時の温度が $10 \sim 30 \mathrm{C}$ の範囲内にお いては，本病菌の不活化速度は温度が高いほど速かで
あった。これは, サイレージ発酵の過程に括ける糸状 菌菌密度の減少が試料の発酵温度が高いほど速かであ るとする報告3゙や，たん水土壤中に和けるフザリウム 病菌の死滅が, 高い温度下に拈いて,より速かである とする報告 ${ }^{4,5,6)}$ に一致する。これらの現象は，40C 付 近あるいはそれ以下の温度範团の嫌気的条件下に拉い て生じ，それらの温度範囲内では温度が高いほど速か であるという共通点を有して扣り，興味深い。筆者ら の見出したダイコン残さの嫌気的発酵過程に和けるダ イコン萎黄病菌の不活化現象とその機構については今 後の検討課題である。

本報告を草するにあたり，御校閲いたたいた当場環 境部長下村徹博士に深謝の意を表する。

（昭和58年 4 月 22 日受理）

2) 須藤 浩 (1960). 牧草講座 2, 利用編 (三井計夫ほ核編). 朝倉書店, 東京. pp. 202-218. 3) 佐々木 博 (1972). 北大農邦文紀要 8:188-251. 4) Stover, R. H. (1954). Soil Science $77: 401-404$, 5) 孫工弥寿雄・喜多孝一 (1978). 日植病報 $44: 367,6$ ) 小玉孝司・福井俊男 (1982). 同上 $48: 570-577$. 